\title{
Evolution of the sustainable tourism concepts
}

\author{
Vasja Roblek ${ }^{1^{*}}$, Danijel Drpić́ ${ }^{2}$, Maja Meško ${ }^{3,4}$ and Vedran Milojica ${ }^{5}$ \\ 1 Faculty of Organisation Studies in Novo mesto, 8000 Novo Mesto, Slovenia; vasja.roblek@gmx.com \\ 2 Polytechnic of Rijeka, 51000 Rijeka, Croatia; ddrpic@veleri.hr \\ 3 Faculty of Organizational Sciences, University of Maribor, 4000 Kranj, Slovenia; maja.mesko@um.si \\ 4 Faculty of Management, University of Primorska, 6000 Koper, Slovenia \\ 5 PAR University College Rijeka, 51000 Rijeka, Croatia; vedran.milojica@gmail.com \\ * Correspondence: vasja.roblek@gmx.com
}

\begin{abstract}
Analytical study presents the evolution and change in content over time and the emergence of different sustainable tourism (ST) concepts in tourism and hospitality. For this purpose, a Comparative Automated Content Analysis (ACA) analyses scientific articles published between 1990, when the first article in this field was published in the Web of Science (WOS), and the end of 2020. With the ACA for analysis papers research, this research helps explain why and how changing business models cross the time, organizational processes, importance of information and communication technologies in sustainable tourism strategies, green investments, sustainable standards in tourism and hospitality, and sustainable reporting.
\end{abstract}

Keywords: sustainable hospitality; sustainable tourism; holistic sustainability; ESG; automated content analysis

\section{Introduction}

The concept of sustainable tourism development (STD) has emerged due to decreasing the consequences of mass tourism in the last forty years. The first important document presents the sustainable tourism (ST) documented Rio +20 [1]. The document states that "the only correct way to develop society is to alleviate poverty, strive for a society of social justice and conserve natural resources" [2]. Therefore, it can be concluded that ST provides guidelines for developing tourism in environmental, social, eco-nomic, and climate-sensitive planning or management [3]. However, based on a literature review, we can assess that the authors define sustainable tourism differently in their works. In terms of content, the concept is divided into uncovering natural sustainability [4], which leads to the emergence of the terms ST [5], eco-tourism [6, 7] and green tourism [8], and the emergence of social sustainability, within which the terms re-sponsible tourism and ST appear [9].

It is also necessary to mention the role of innovative technologies for ST. Innovative technologies in ST impact organizational efficiency, productivity, and environmental sustainability [10]. The development of technologies also contributes to the development of society. The importance of residents for ST is also natural as the main initiative and action must come from them. Likewise, managers must be equipped with practical tools and mechanisms to make the best possible decision in line with the destination's ST and enterprise. However, with the risk of negative consequences resulting from the application of new technologies, on the other hand, we see them as a potential to eliminate threats to sustain-able environmental development. In this article, the authors present the evolution phases of ST by analyzing research articles published from 1990 to 2020. Since there are many papers, it is necessary to apply an alternative analytical approach that will enable us to categorize the data effectively and successfully. The categorization process enables researchers to explain the research phenomenon appropriately and clearly. Furthermore, the authors used automated content analysis to determine the researcher's major themes and concepts of interest throughout their historical emergence [11]. 
The paper structure includes next sections: introduction, followed by the research method, including data collection, literature selection, data analysis and ACA findings. The paper concludes with a discussion of the findings and conclusions, including a comparative analysis of the results, research limitations, and future research suggestions.

\section{Research design}

\subsection{Data selection}

A systematic review of the literature was conducted using the Boolean operator (AND): sustainable tourism *, development, tourism *, sustainability and tourism *, sustainable tourism. In addition, the authors used the online Web of Science (WOS) database: Social Sciences Citation Index (SSCI), and Arts and Humanities Citation Index (A \& HCI), to search for scientific journals articles published in the English language.

The article uses the ACA to assess the evolution of knowledge on sustainable tourism and discover previously unexplained knowledge gaps [12]. Figure 1 shows the number of publications classified as ST available at the WOS from 1990 to 2020. The stacked bars indicate the total number of published articles. A total of five thousand three hundred eighteen articles published in 390 peer-reviewed journals were identified in WOS. The literature review is prepared according to the Prisma 2020 technique. The process is presented in Figure 2.

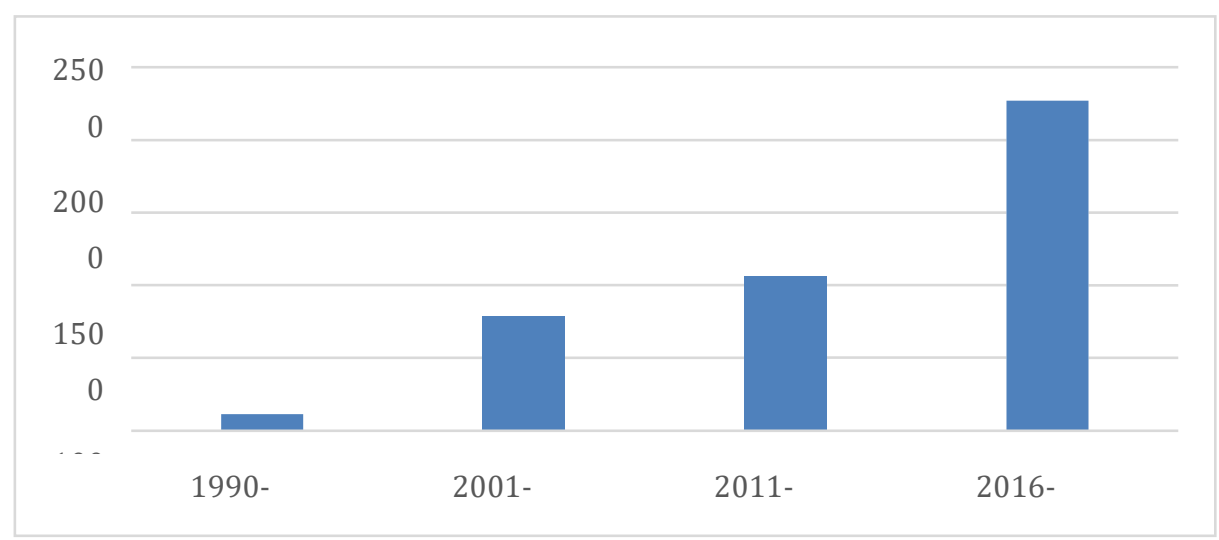

Figure 1. The number of papers classified under ST by the WOS database available each year from 1990 to 2020. Source: Authors' research

After a manual review of titles, abstracts, and keywords, 238 irrelevant articles were excluded. Thus, of the 5,080 articles published in 372 journals, the ACA was implemented. 


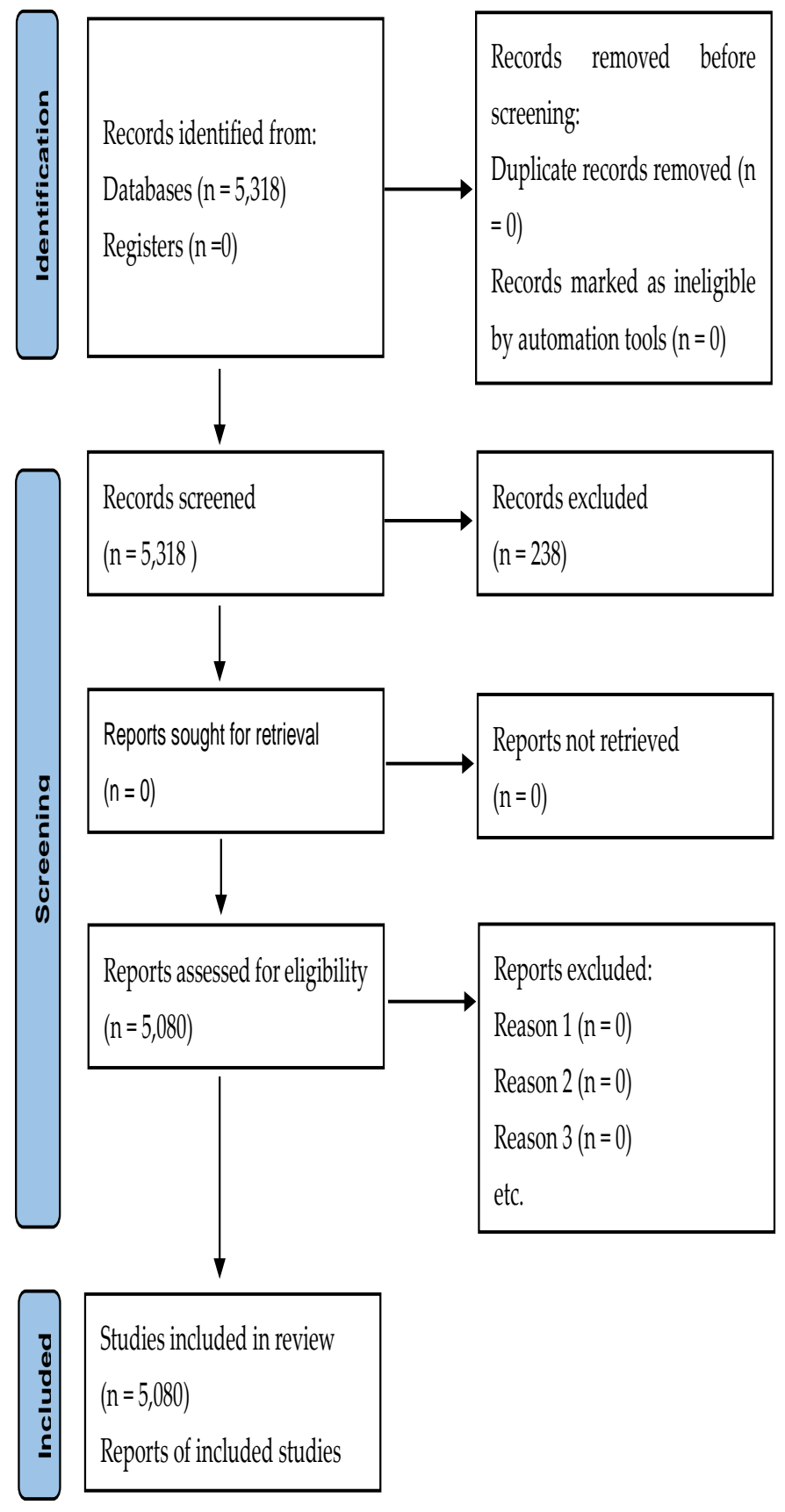

Figure 2. Prisma 2020 flow diagram.

Among the leading scientific journals that have published research on tourism STs between 1990 and 2020 are Sustainability (896 papers), Journal of Sustainable Tourism (633 papers), Tourism Management (239 papers), Journal of Cleaner Production (126 papers), Current Issues in Tourism (113 papers), Annals of Tourism Research (110 papers), Journal of Coastal Research (88 papers), Ocean Coastal Management (87 papers), Tourism Geographies (72 papers) and the Asia Pacific Journal of Tourism Research (71 papers). 


\section{Automated content analysis}

For textual analysis, we used ACA that was performed with Leximancer 5.0. Authors performed ACA (text analysis) with the program using a Bayesian learning algorithm, which allows the decomposition of larger parts of the text into a conceivable number of specific topics in the selected text (terms) [14]. Leximancer created a concept folder based on the relationships between the two topics and terms based on topics and terms.

\subsection{Results and thematic concerns in the scientific journal's articles}

By analyzing the titles, abstracts, and keywords of 5,080 papers published in 372 journals, 45 concepts and four themes were identified. The themes identified in the analysis are "development", "management", "change", and "tourists". Figure 3 presents a concept map based on themes (colored circles) and concepts that form a single theme (text within themes in black font). The importance of the topics is represented in colors' such as "heatmap" (the lighter the topic, the more often it is found in the analyzed text) and size (the larger the topic, the more concepts it contains) [15]. Topics, hits and related concepts.

Table 1. Themes and concepts in the journals in the years from 1990 to 2020

\begin{tabular}{|c|c|c|}
\hline Theme & Hits & Concepts \\
\hline Development & 14100 & $\begin{array}{l}\text { development, tourism, sus- } \\
\text { tainable, local, economic, } \\
\text { community, social, environ- } \\
\text { ment, rural, cultural, herit- } \\
\text { age, residents, framework, } \\
\text { strategies, process, economy, } \\
\text { experience }\end{array}$ \\
\hline Management & 7257 & $\begin{array}{c}\text { management, resources, pro- } \\
\text { tected, natural, region, con- } \\
\text { servation, planning, coastal, } \\
\text { eco-tourism, people, marine, } \\
\text { project }\end{array}$ \\
\hline Change & 4763 & $\begin{array}{c}\text { change, climate, services, } \\
\text { ecological, system, ecosys- } \\
\text { tem, human, changes, water, } \\
\text { quality }\end{array}$ \\
\hline Tourists & 4.606 & $\begin{array}{l}\text { tourists, growth, urban, coun } \\
\text { tries, energy, food }\end{array}$ \\
\hline
\end{tabular}

Source: Authors' research

Table 2 presents the results of "more quantitative analysis in ranked bar chart format of the most central concepts with a particular category - defined via a measure of the combination of their strength and frequency characteristics. Prominence is given by the joint probability/product of marginal probabilities; for example, given the attributes a and category c, prominence is equal to (the co-occurrence count for a and c) / (total number of context blocks in data set)/ (occurrence of a / number of context blocks) $\mathrm{x}$ (occurrence of $\mathrm{c}$ / number of context blocks)" [16].

Table 2. Ranked concepts for categories overview 
a) Category: 1990-2000

\begin{tabular}{|c|c|c|c|}
\hline Concept & $\begin{array}{c}\text { Rel. } \\
\text { Freq. } \\
\text { (\%) }\end{array}$ & $\begin{array}{c}\text { Strength } \\
(\%)\end{array}$ & Prominence \\
\hline coastal & 18 & 9 & 4 \\
\hline conservation & 16 & 7 & 3,7 \\
\hline protected & 16 & 6 & 3 \\
\hline management & 20 & 5 & 2,8 \\
\hline planning & 11 & 5 & 2,7 \\
\hline resources & 15 & 5 & 2,6 \\
\hline local & 20 & 4 & 2,5 \\
\hline community & 16 & 4 & 2,4 \\
\hline tourism & 72 & 3 & 1,7 \\
\hline economic & 13 & 3 & 1,5 \\
\hline \multicolumn{4}{|l|}{ Authors source. } \\
\hline \multicolumn{4}{|c|}{ b) Category 2001-2010 } \\
\hline Concept & $\begin{array}{c}\text { Rel. } \\
\text { Freq. } \\
(\%)\end{array}$ & $\begin{array}{c}\text { Strength } \\
(\%)\end{array}$ & Prominence \\
\hline conservation & 6 & 23 & 1,3 \\
\hline protected & 6 & 20 & 1,1 \\
\hline resources & 7 & 20 & 1,1 \\
\hline region & 6 & 20 & 1,1 \\
\hline management & 7 & 17 & 1 \\
\hline local & 8 & 16 & 0,9 \\
\hline economic & 7 & 16 & 0,9 \\
\hline community & 6 & 15 & 0,9 \\
\hline tourism & 33 & 14 & 0,8 \\
\hline sustainable & 6 & 10 & 0,6 \\
\hline
\end{tabular}

c) Category: 2011-2015 


\begin{tabular}{cccc}
\hline Concept & $\begin{array}{c}\text { Rel. } \\
\text { Freq. } \\
\text { (\%) }\end{array}$ & $\begin{array}{c}\text { Strength } \\
\mathbf{( \% )}\end{array}$ & Prominence \\
\hline conservation & 4 & 29 & 1 \\
change & 4 & 25 & 0,9 \\
community & 5 & 22 & 0,8 \\
management & 6 & 22 & 0,8 \\
local & 6 & 21 & 0,8 \\
social & 5 & 21 & 0,8 \\
tourism & 31 & 21 & 0,7 \\
economic & 6 & 20 & 0,7 \\
resources & 4 & 20 & 0,7 \\
sustainable & 7 & 20 & 0,7 \\
\hline
\end{tabular}

d) Category: 2016-2020

\begin{tabular}{cccc}
\hline Concept & $\begin{array}{c}\text { Rel. } \\
\text { Freq. } \\
\text { (\%) }\end{array}$ & $\begin{array}{c}\text { Strength } \\
\mathbf{( \% )}\end{array}$ & Prominence \\
\hline growth & 6 & 68 & 1,3 \\
sustainable & 13 & 67 & 1,3 \\
social & 8 & 63 & 1,2 \\
rural & 6 & 61 & 1,2 \\
tourism & 49 & 61 & 1,2 \\
economic & 9 & 59 & 1,2 \\
community & 7 & 57 & 1,1 \\
local & 9 & 56 & 1,1 \\
\hline
\end{tabular}




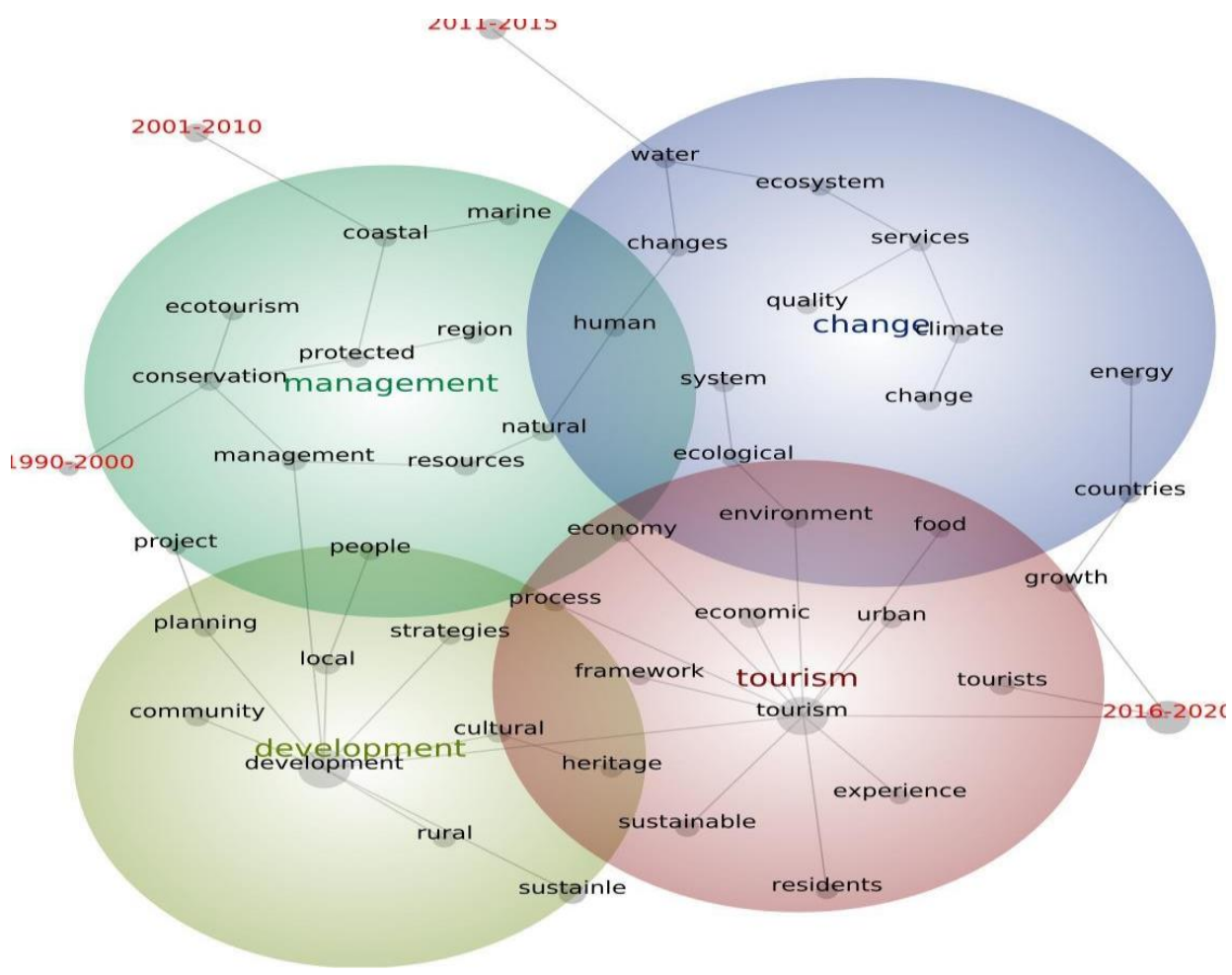

Figure 3. Timeline of the development and importance of sustainable tourism from 199 to $2020(n=5.080)$.

\section{Discussion}

\subsection{Evolution of sustainable tourism development between 1990 until 2021}

\subsubsection{Category: 1990-2000}

Papers published between 1990 and 2000 deal with environmental protection, ecotourism and sustainable tourism development. In 1992, at a conference in Rio de Janeiro, Agenda 21, the Rio Declaration on Environment and Development and the Statement of Principles for the Sustainable Management of Forests were adopted. Agenda 21 has influenced the emergence of the development of sustainable tourism worldwide [17].

Concepts of eco-tourism (theme management) and green tourism are concerned with the establishment and management of appropriate strategies/action plans for eco-tourism, green tourism and sustainable tourism development Not only to improve the local economy and in many underdeveloped areas but also to mitigate conflicts among the locals and achieve the goal of biodiversity conservation [18, 19]. During the period 1990-2000, eco-tourism became a sustainable alternative to mass tourism in protected areas (national parks) and provided benefits to local communities that bear the highest opportunity costs of conservation. Thus, the concept of "ethnic tourism" evolved. The authors, mainly from developing countries, point out the unequal distribution of employment and revenue in tourism, as park managers favor external operators over local people. They also note that eco-tourism has not yet established itself in the national parks' peripheral areas [20]. (Walpole \& Goodwin, 2000). It is also important to point out the awareness regarding African countries of the need to regulate wildlife hunting and establish a model for an optimal revenue/payment system that benefits the local population and the wildlife conservation program. At the same time, it is necessary to introduce other non-consumptive forms of nature-based tourism, such as bird watching and photographic tourism [21].

Eco-tourism has emerged as a form of future tourism. The importance of decommodifying social policies that are universally accessible to all and prioritize social goals and 
human rights, such as the right to work or a decent standard of living, over economic values and goals has also come to the fore. The distinction between commodification and decommodification can also be applied to eco-tourism development. Commodification processes occur when the outcome is defined as the economic value of a product. The problem of eco-tourism's focus on commodifying nature in search of global profit and the tourist dollar in capitalist economies is highlighted. The negative impact of such a path on host communities requires decoding policies for sustainable eco-tourism. Rather than looking almost exclusively at industry profit, eco-tourism must add social value to the local environment and economy [22].

Approaches that make this possible include tourism approaches of ethnic communities, the quality of tourism interactions with local communities and nature, an ethic that cares about protecting the natural environment, and a willingness to understand the consequences of human actions in the natural environment for the local economy [23].

Therefore, it is important to adopt innovative processes and business models and develop resilience to change and global (local) host communities. It is also important to develop criteria for a possible match between the consequences of globalization on tourism and the preservation of tradition, cultural identity and heritage (destination culture) in the eco-tourism industry [24, 25].

The main problem of sustainable local eco-tourism industries is that global processes can come into play. Solutions for local eco-tourism development should also be incorporated into policies for more informal practice's, such as government regulation and industry self-regulation through greater adherence to codes of ethics and certain restrictions on tourism capacity at host sites $[22,26]$. However, care should be taken not to over-apply strict sustainability criteria. It is problematic as even such development practices can create spillover effects that hinder strong sustainability where tourism is concentrated, dispersed or low activity. Their limited value justifies tourism-focused development policies (thematic development) in achieving strong sustainability goals at broader sectoral levels. Accordingly, it is argued that in addressing these issues, policy should focus on enabling coordinated strategic planning interventions rather than relying on market-based tools and processes [27]. The question of whether eco-tourism is sustainable has also come to the fore [28].

At this point, it is necessary to ask whether tourism contributes to sustainable development and how. First, it is necessary to separate the meaning of tourism's contribution to sustainable development from sustainable tourism, as the development approach in a particular sector may overlook important links to other sectors [7]. Secondly, if tourism contributes to sustainable development, its economic performance, ecological sensitivity and cultural appropriateness must be ensured. On the other hand, eco-tourism has emerged as sustainable tourism [29]. It should be emphasized that when interpreting sustainable tourism and the impact of tourism on sustainability, attention must be paid to possible terminological ambiguities. In the late 20th century, it was assumed that ecotourism would challenge destinations for economic, environmental, and cultural reasons, even in its purest form. It is a particularly true presumption in cases where destinations compete for limited resources and displace existing purposes and users. It should be emphasized that sustainable tourism and eco-tourism are not synonymous, as certain forms of eco-tourism may not be sustainable. If eco-tourism contributes to sustainable development, it must be carefully planned and managed [7].

Regarding the connections between tourism and environmental protection (theme management), it should be noted that the articles in this period focused on marine and coastal management. In these articles, the authors explore and present approaches to ocean governance in which the development and implementation of regional ocean plans play an important role [30,31]. These projects are "based on large marine ecosystems designed to integrate sectoral commercial interests and conservation objectives" [32]. With the development of regional marine plans, detailed policies also need to regulate different marine uses and impacts and marine regions. These policies address various policy instruments and their potential roles in the management and use of marine resources. The 
so-called incentive instruments include financial and economic instruments, legal and regulatory instruments, education, co-management, voluntary approaches, communitybased mechanisms and research. The purpose of these potential management tools is to ensure: water quality of rivers, estuaries and oceans; help create conditions for sustainable fisheries; ensure sustainable marine tourism and recreation; manage conflicts between users and stakeholders; ensure environmentally friendly maritime transport, and oil and gas exploration and mining [31,33]. Research into the importance of renewable energy in the context of sustainable destination development has also come to the fore [34].

Policies and guidelines for managing supply and consumption play an important role in tourism and sustainable development. For example, enterprises must consider environmental aspects when carrying out their activities and harm the operating environment. Therefore, in the context of sustainable development of destinations, it is necessary to focus on the role of enterprises in the tourism industry and focus on the management and control of supply (demand) and demand (consumption) policies [35]. Based on the guidelines, the regulator can make recommendations to improve the implementation of tourism services. The regulator achieves this by carefully reviewing business and environmental measurements and training tourism staff to manage destinations in line with the concept of sustainable development and raising consumer awareness of the importance of and opportunities for sustainable behavior [36]. Tourism enterprises need to consider supply and demand in the context of their activities. Based on the analyses, this will provide them with the necessary information about business shortcomings that will enable them to eliminate unsustainable business processes in the future. All actors operating within the value and supply chain of the organization and destination are important for sustainable tourism development. Therefore, it is necessary to manage supply chains and destinations on the one hand, and on the other hand, to take care of consumer education through methods that allow tourism to be aligned with sustainable development. Enterprises must control the entire supply chain and ensure that all members strive for sustainable tourism $[36,37]$.

\subsubsection{Category: 2001-2010}

Agenda 21 was strongly reaffirmed during this period in the Program for the Further Implementation of Agenda 21 and the commitments made to Rio Principles at the World Summit on Sustainable Development (WSSD) in Johannesburg, South Africa, in 2002 [38].

The articles on sustainable tourism development (theme development) focused on developing sustainable tourism policies that would encourage new business forms, increase employment and support landscape conservation. Thus, the European Charter was adopted for Sustainable Tourism in protected areas. The Charter provides a reference methodology for local development and involves local stakeholders in defining sustainable policies. It has been shown that in many cases, integrated sustainability indicators are developed through a participatory process. These indicators include indicators suitable to measure and assess the evolution of development policies over time, integrate sustainability to reduce negative environmental impacts and promote the preservation of local and traditional values [39].

To develop sustainable tourism, it is also important to focus on integrating cultural heritage into tourism products. Articles dealing with this topic come from the resourcebased view theory, in which cultural heritage is understood as an important resource for destinations seeking sustainable positioning [40]. However, the difficulty of transforming heritage from an asset into a resource often stems from the lack of convergence between institutions responsible for heritage conservation and tourism. Therefore, it is necessary to establish coordination based on a three-phase process. Such coordination addresses management paradoxes essential for a joint effort to preserve cultural heritage and develop tourism [41].

Also, in this period, there are projects of conversion to renewable energies (theme management) to improve the environmental conditions of the tourist destination (e.g., reduction of pollution), which will have a positive impact on the sustainable development of the destination and improve the living conditions of the locals [42]. 
Thus, the Sustainable Development Guidelines (theme development) for the period 2001 to 2020 exhorts that the guideline for tourism development must include economic growth and become a tool for improving the quality of life and employment, especially in rural areas $[43,44]$. Therefore, it is necessary to promote innovation and quality standards, focus on sustainable responsibility, develop skills, promote sustainable and viable products and use tourism to promote social inclusion, territory and politics [45].

An important part of the research in environmental protection (theme management) was marine and coastal management. The articles point to the importance of incentives for poverty alleviation and empowerment, including education and employment, for a large segment of the coastal population. Employment opportunities lie in marine and coastal resources and services [46]. There needs to be the political will to fund and prioritize projects based on the implementation of relevant international conventions, particularly UNCLOS with the exclusive economic zone, Common Human Heritage and other provisions, Agenda 21, UNCED and the oceanic goals of WSSD 2002 [47]. Programs must ensure that the overexploitation, depletion and degradation of resources, habitats and coastal ecosystems, global change and economic transformation, and the social situation of poverty, employment and inequality are addressed. Coastal populations' socioeconomic and human security needs must be met to adequately manage and protect natural resources, including ecosystems and their services, habitats, and biodiversity. One way to achieve this goal is to represent and grow about $50 \%$ of the world's population, fight poverty, and cope with insecurity and changing employment, environmental and sustainability conditions through appropriate coastal and marine resources management. It includes providing education and knowledge about these resources and their proper use. These include energy, water, food, transportation and trade, communications, coastal development, tourism, nautical, recreation and ecosystem services, and the need for proper management $[48,49]$.

In the context of environmental protection, the authors also stress the need to protect mountains and establish sustainable mountain tourism because, in mountainous areas, human survival is closely linked to ecosystems. Therefore, it is necessary to ensure proper coexistence management between locals and stakeholders [50,51].

One of the consequences of mass tourism mentioned in studies is the construction of airport infrastructure (thematic development) to meet the increasing demand for tourism and air travel in general. This leads to problems in ensuring sustainable development. To ensure sustainability in the aviation sector, an alternative to the traditional airport landing fee pricing structure would need to be found that reflects the real costs (both financial and environmental) that aviation imposes on others $[52,53]$.

With the accelerated development of mass tourism, tourism development (theme development) between 1990 and 2010 became the backbone of developing economies in many developing countries (South America, Africa, and Asia). Its proponents argue that it contributes to sustainable development, poverty reduction and integration into a globalized economy [54]. However, scholars and activists began to draw attention to ecological degradation, profit skimming, distorted cultural patterns, rising land values, and prostitution associated with tourism. In addition, it is pointed out that tourism perpetuates existing inequalities, fiscal problems, and social tensions $[55,56]$. In the context of tourism development in developing countries, it has been noted that there are cases of devaluation and marginalization of workers and sexualization of their labor [57]. At best, most people are pushed to facilitate low-paying jobs in the formal sector, unemployment or fleeting activities in the informal sector that involve commodifying sexuality and affective relationships [58].

\subsubsection{Category: 2011-2015}

Articles published between 2011 and 2015 are characterized by focusing on tourism as a major user of the environment. (Topic change) Furthermore, its role in indirectly contributing to environmental degradation. This is mainly due to the increase in tourist travel, 
which harms the environment and reduces the possibilities of sustainable tourism development in the long term. If we want to reverse the negative trends in the impact of tourism on the environment, we need to promote activities and services that have a low impact on the environment [59]. It is necessary to focus on eco-tourism, the development of tourism in rural environments, including promoting agrotourism and wine tourism, tourism in protected areas, cultural tourism and adventure tourism [60]. It is also necessary to raise the awareness of tourists and ensure that they change their behavior and find satisfaction in sustainable forms of tourist services and products offer.

The results of global studies have shown that tourists' understanding and receptiveness to sustainable forms of travel is sufficient. However, the supply of such services was still modest during this period due to the unawareness of such a supply among tourists and the insufficient fulfilment of the requirements by the users of such tourist services, especially in terms of behavior [61].

After 2011 the eco-tourism became important because of its impact on environmental protection (theme change). If we wish to achieve sustainable eco-tourism development, it is necessary to achieve the right combination of economic prosperity and ecological protection and social benefits. Therefore, in eco-tourism development processes, it is necessary to coordinate interests between the main stakeholders (government, tourism enterprises and tourists), significantly impacting the decisions taken and the satisfaction itself. Only mutually coordinated stakeholders will significantly impact sustainable eco-tourism development, which will trigger new styles of economic development related to sustainable eco-tourism and the environmental protection system using measurement approaches [62]. Such examples are visible in the context of trails where people both recreate and observe nature and wildlife. However, few studies have combined ecological and cultural attributes to assess the eco-tourism potential of trails in terms of recreation planning. Seasonality has also been neglected in tourism research. To spread tourists throughout the year and mitigate the negative impacts of mass tourism events, hiking areas began to adopt an integrated framework for assessing the eco-tourism potential of trails, including species, habitats, landscape values and local heritage, into seasonal account differences [63].

In the context of sustainable development and environmental protection (theme change), it is necessary to mention lakes as one of the world's most popular tourist destinations. Climate change greatly impacts the characteristics of lakes as a tourism market because the climate is an important source of lakes and coastal tourism. Therefore, it is necessary to anticipate the possible impacts of global climate change on lakes, as it is emphasized that the impact of climate change on tourism will mainly affect coastal and mountain areas [64]

With the rapid development of tourism resources and the tourism industry, there has been a conflict between economic growth and the ecological environment (theme change). In the context of the harmonious development of the ecological environment, it is also necessary to find the right paradigm for tourism's economic development. The paradigm must be substantially calibrated to protect the sustainable use of eco-tourism resources, focusing on the energy self-sufficiency of tourist facilities (introduction of solar panels, heat pumps) and emphasizing the constant development of various stakeholders who must be aware of the need for environmental balance [65].

Sustainable tourism has emerged as the dominant paradigm for managing visitor use in protected areas. An important consequence of this approach is that protected area managers (nature and landscape parks) focus on important issues for the development and protection of protected areas. For example, after 2010, the European Union focused on a landscape approach (such as the European Landscape Convention [ELC]). These strategies seek sustainable landscape conservation and often identify tourism as an important development strategy (theme development).

The articles also dealt with the maritime and coastal cultural landscape. Research has focused on both the land and the sea and below sea level. These areas represent an im- 
portant part of human cultural resources in coastal areas (topic change). In the past, integrated coastal zone management (ICZM) has indeed theoretically addressed the importance of cultural ecosystems. However, cultural resources have been more or less ignored in integrated coastal management plans. The consequences of neglecting cultural resources can be seen in the loss of cultural identity associated with certain habitats. Environmentally, there is a loss of development opportunities in tourism, recreation and education, and a decline in local knowledge of ecology, skills and technologies related to habitat management. Thus, it is coming to the loss of opportunities related to social and cultural capital. In the context of both the documents and the case studies, it is clear that no adequate definition and evaluation of coastal heritage has been made. However, it is also necessary to point out that such coastal cultural heritage is not considered a resource with great benefits for development and people [66].

In rural tourism development (theme development), the development strategy of some rural areas has come to the fore. The landscape has become the central attraction for visitors. In rural areas, tourists are attracted by the different vegetation and colors and architectural heritage, which prove to be key elements of the tourist experience, but which are followed by a complex group of mostly non-visual stimuli, including sounds, smells, tastes, human contacts, nature in its broadest sense and the past [67]. If regions are to become a center of tourist interest, landscape development actors must act at all levels to achieve a comprehensive integration of tourism and landscape management in terms of marketing, product development and nature conservation. The authors noted the differences between visitor groups in their research, suggesting that different visitor groups require different approaches [68, 69].

In the context of managing rural tourism development, stakeholders face several challenges, such as managing factions and enclaves within the community, catering for new entrants in terms of risks and vulnerabilities, ensuring long-term commitment of leaders, creating continuity from one leader to the next, and coordinating joint management across many governmental and non-governmental organizations. Research shows that each leader uses a different approach, including professional, shared/authentic, and authentic leadership [70]. For rural tourism operators, the success of connecting and networking social capital within the state is important, regardless of their management approach. The external connection between residents allows for the joint promotion and design of tourism development and enables an approach to develop a thematic village concept. However, it should be noted that the social orientation and inward-looking perspective of community tourism may hinder the effective adaptation of local resources to market needs, thus preventing sustainable growth of community-based rural tourism [71]. In the development of rural tourism, agricultural heritage has become increasingly popular as a tourist destination. However, the arrival of large numbers of tourists poses significant challenges to these fragile ecosystems. In particular, water resources are under extreme pressure. Therefore, before promoting sustainable tourism, an assessment of the water footprint of tourism is proposed [72].

Climate change and coastal development (theme change) are affecting coastal erosion, leading to a deterioration in the quality of beaches and thus a decline in the attractiveness of coastal areas, which in turn leads to a deterioration in economic impact [73]. Social responses to these problems have resulted in hard/soft engineering methods to mitigate erosion and provide quality rewards that support the value of recreational beaches [74]. Management approaches have demonstrated the ineffectiveness of strict measures to stop erosion and its negative impact on the quality of the environment. Such management approaches have been used as an emergency response to problems and have not been based on sufficient knowledge of the potential consequences. In contrast, successful experiences with soft methods have allowed the natural conditions of beaches to be maintained and the quality of tourism to be improved. Awards for the quality of beaches have made it possible to meet the needs of tourists and promote a good image of beaches [75]. Due to the numerous unsustainable practices of the tourism industry, it is necessary to examine the possibility of establishing measures in real environments based on the criticisms made 
in the theoretical discussions. Therefore, it is necessary to include the management of social impacts in the context of tourism business in the business strategies of tourism enterprises and destinations [76]. In developing research methods, social management systems, environmental innovations and initial actions, a pragmatic approach is required, based on actual operational constraints and existing systems in the tourism industry. For example, hotels usually introduce innovations in their operations that are important for protecting the environment. However, soft measures in human resource management are also important, including managerial salaries based on environmental performance, employee satisfaction, environmental accounting and education. Managers must be aware of the importance of using environmental management systems and linking them to introducing innovations that reduce operating costs [77].

Nevertheless, it is also important that hotel categorization (stars) is linked to innovative solutions that provide a higher quality level of hotel infrastructure, including wastewater treatment, noise reduction, soundproofing and improved visual impact [78]. At the same time, hotels must achieve high employee satisfaction by introducing water conservation and noise reduction innovations, requiring employee involvement. In contrast, the role of information sources in interpreting innovation uptake varies according to the technical complexity of the innovation [79].

In the 21st century, a new form of sustainable tourism has emerged named slow tourism (theme development). The definition of slow tourism states that it is a form of sustainable tourism that emphasizes the importance of tourism campaigns based on a slow and restful orientation to achieve life values and improve well-being. However, despite sufficient theoretical foundations, soft tourism faces challenges in practice. For this reason, it would be necessary to prepare training for both managers and consumers and create an economic value chain that allows for the formation of industry alliances. Thus, in practice, a slow tourism architecture has already been developed to promote slow tourism [80].

Issues of sustainable tourism in the context of global urban development (thematic change) have also come to the fore. Unlike in the past, city governments can now integrate sustainable tourism development measures into urban development projects. However, the municipality must consider environmental issues and the global dimension of the proposed measures in doing so. Technological development has enabled stakeholders to solve socio-urban problems and social demands by transforming cities into tourist destinations [81].

\subsubsection{Category: 2016-2020}

In the last research category, covering sustainable tourism development from 2016 to 2020, we focus on the 2030 Agenda for Sustainable Development, published by the United Nations in 2015. The agenda calls for the implementation of 17 Sustainable Development Goals (SDGs). In terms of content, the agenda regulates and links the three dimensions of sustainable development - economic, social and environmental - and requires that all countries in the world Sustainable Development Goals implement them by 2030 [82]. From this point of view, it has also become important for the further development of tourism (theme tourism), the lead stream sector in many developing countries, through which all three themes can be efficiently achieved [83, 84]. There is also a need to address architectural heritage, especially tourist heritage destroyed during urban renewal, especially in developing and underdeveloped countries where stakeholders have no interest in protecting cultural heritage. Cultural Heritage Tourism (CHT) has become an important part of the tourism industry. Therefore, it is important to assess the sustainability of CHT objectives for tourism development. Most existing studies have examined the desired sustainability of eco-tourism, considering three stakeholders: Resource management, tourism and the local community [85-87], but it should not be forgotten that it is important for tourism businesses to be involved in CHT-related studies for destination sustainability [88]. To further tourism development (theme tourism), it is important to emphasize the quality of tourism services, disruptive innovations in the tourism sector, and sustainable development. All these factors directly support SDG-8 (i.e., decent work 
and economic growth), SDG-9 (i.e., industry, innovation and infrastructure), SDG-12 (i.e., responsible consumption and production) and SDG-13 (i.e., climate change) [89]. The agenda program promotes the further development of sustainable tourism, drawing attention to the need to monitor the use of natural resources and encourage efforts to maintain and create jobs for members of local communities while promoting local culture, services and products and the sustainable use of marine resources, to maximize economic benefits for small developing islands, developing countries and underdeveloped countries [90]. Thus, community members' support has become one of the key factors for the sustainable tourism industry's success in all areas, including rural areas [91]. The continuous development of the community must be balanced across all dimensions of sustainable development. This can be achieved through an innovative approach to developing social entrepreneurship in tourism, providing local communities with new jobs and opportunities for young people to stay in rural areas and contribute their knowledge and ideas to further community development.

In the last 30 years, the mass has led to economic problems and socio-cultural instability in tourist destinations, which is reflected in the increasing exodus of residents from tourist destinations due to the oversaturation of day tourists in well-known tourist destinations, which could be solved not only by introducing higher tourist taxes and limiting air and sea traffic but also by the digital transformation of tourism and other services. Social entrepreneurship can help develop sustainable, innovative (technological) approaches that help reduce human emissions and thus increase community development [92]. It is identified that state-of-art information and communication technologies play a crucial role when it comes to the revival of the (sustainable) tourism sector in the postCOVID era, especially data mining [93, 94], virtual reality [95], augmented reality [96] and Internet of Things (IoT) [97]. Data mining aims to discover useful patterns and knowledge from enormous data about events of importance, users, and their interactions with others and the environment. Typical scenarios include tourist segmentation based on clustering, tourist number prediction relying on regression, excursion and services cross-selling based on association rule mining and booking cancellation prediction leveraging classification methods $[93,94]$.

In fig. 4 is presented the role of so called new-age-technologies that will enable the sustainable development of tourism in post Covid-19 era. Virtual reality (VR) provides a fully immersive interactive experience within virtual 3D worlds. In this environment, the user can explore the surroundings and interact with 3D objects. Furthermore, different responses can be generated as an outcome of this interaction, such as animation, text visualization, voice and multimedia playback. Therefore, this kind of technology is highly relevant for tourism, as it enables novel usage scenarios, such as virtual tours, museum and destination exploration [98]. On the other side, augmented reality (AR) allows the overlay of animated 3D objects and multimedia content on realistic images coming from the camera stream. This way, many interesting use cases in the tourism sector become possible, such as $3 \mathrm{D}$ historical reconstruction enabling to relive the past at historical locations, self-guided sightseeing and exploration [99], which are especially important for post-COVID tourism [100] under new circumstances [101]. Finally, the IoT refers to the network of small, low-power devices ranging from affordable credit card-sized microcomputers to sensors and smart tags. Apart from tourist experience enhancement, IoT is crucial for tourism in the post-COVID era, as these affordable systems are responsible for tasks that aim to reduce this disease's spread, such as mask detection, contact tracing, and air quality control [100]. Moreover, assistive robots based on affordable IoT devices can be used for different purposes, such as surveillance of monuments and museums or interaction with tourists [102]. 


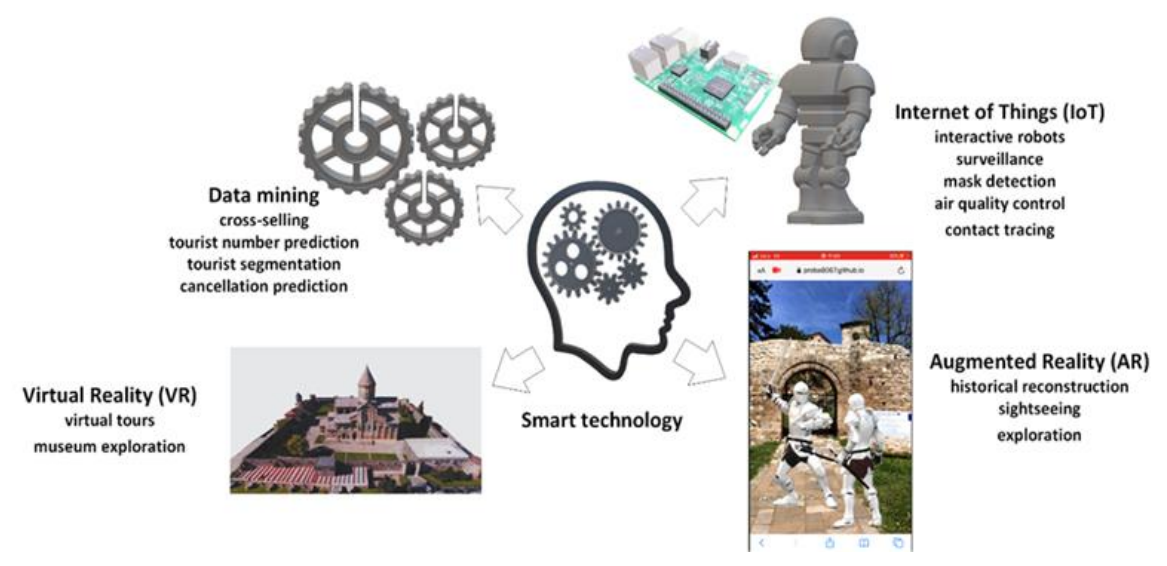

Figure 4. Role of new-age-technologies for sustainable tourism in postCOVID era [103]

Data mining aims to discover useful patterns and knowledge from enormous data about events of importance, users, and their interactions with others and the environment. Typical scenarios include tourist segmentation based on clustering, tourist number prediction relying on regression, excursion and services cross-selling based on association rule mining and booking cancellation prediction leveraging classification methods [93]. Virtual reality (VR) provides a fully immersive interactive experience within virtual 3D worlds. In this environment, the user can explore the surroundings and interact with 3D objects. Furthermore, different responses can be generated as an outcome of this interaction, such as animation, text visualization, voice and multimedia playback. Therefore, this kind of technology is highly relevant for tourism, as it enables novel usage scenarios, such as virtual tours, museum and destination exploration [99]. On the other side, augmented reality (AR) allows the overlay of animated 3D objects and multimedia content on realistic images coming from the camera stream. This way, many interesting use cases in the tourism sector become possible, such as $3 \mathrm{D}$ historical reconstruction enabling to relive the past at historical locations, self-guided sightseeing and exploration [100], which are especially important for post-COVID tourism under new circumstances [101]. Finally, the IoT refers to the network of small, low-power devices ranging from affordable credit card-sized microcomputers to sensors and smart tags. Apart from tourist experience enhancement [97], IoT is crucial for tourism in the post-COVID era, as these affordable systems are responsible for tasks that aim to reduce this disease's spread, such as mask detection, contact tracing, and air quality control. Moreover, assistive robots based on affordable IoT devices can be used for different purposes, such as surveillance of monuments and museums or interaction with tourists.

Social innovation can play an important role in enabling resilient tourism in the postCovid-19 era [104, 105], as Covid-19 is expected to influence the decline of mass tourism and accelerate demand for individual travel and sustainable tourism options [106]. Seeking social contact with locals will come to the fore, and visitors will no longer be satisfied with visibly staged and artificial representations of local cultures [107]. (Romagosa, 2020). The demand for locally grown food (and drinks) is also expected to increase. There will be a need to offer safe and high-quality food and bring more creativity to gastronomy based on local characteristics but in line with current trends). Small businesses, which is emphasized in rural areas, are important to the development of sustainable and recreational tourism. Successful environments have created partnerships and established a sustainable tourism discourse through linkages that increase social capital. Local development agencies were established in Europe and elsewhere (e.g., Japan) in the late 20th century to connect local communities to constructively integrate social capital and obtain 
funding for local business projects that led to the emergence of oriented sustainable tourism services [108].

Studies are skeptical about the development of social contact in tourism and emphasize the need to develop concepts of social contact to understand the relationship between tourists and locals and develop approaches that help develop affection and maintain relationships between tourists and locals $[109,110]$. A systemic resilience approach is offered to increase the number of actors involved in activities to maintain and develop sustainable approaches to the destination. In the context of community governance, it is necessary to develop relationships between stakeholders based on mutual respect and equality, as this is the only way to formulate and decide on strategies for the further social development of the community. Systemic resilience also enables the creation of elements of social capital that are essential for successful joint management of natural resources (cooperation, transparency, reciprocity and effective communication) [11].

\section{Conclusion}

This paper aims to construct and analyze mixed-methods research on sustainable tourism using the ACA. The results show some overlaps between the concepts that have emerged over time. From the analysis results, it can be concluded that the topic focuses on changes in business models, adoption of organizational processes related to climate change mitigation delivery, adoption of clean and smart technologies, the importance of cultural heritage for sustainable tourism product concepts, rural development, green investment, sustainable standards and sustainable reporting.

An important step towards sustainable development in the tourism industry was taken in 1992 at the United Nations Conference on environment and development in Rio de Janeiro. Since this conference, ST has been considered one of the most important global economic, social, and environmental development issues. ST comes to the fore when it focuses on a specific sector or parameters within the tourism and hospitality industry. Parameters include socioeconomic impacts and measures to protect and preserve natural and cultural heritage, the supply of natural resources such as water and energy, and the concept of developing tourism policies in harmony with the environment and people.

Another important step towards further socioeconomic and environmental development, which also plays an important role in promoting sustainable tourism, is the 2030 Agenda for ST, adopted in 2015 in the United Nations. It focuses on the 17 ST Sustainable Development Goals (SDGs) that businesses must incorporate into their criteria to ensure sustainable operations.

For many countries, especially underdeveloped and developing countries, tourism is the main economic sector that provides economic growth. In these countries, tourism and hospitality are important economic units for local employment and maintaining and improving living standards. However, due to poorer environmental standards, the countries are more exposed to the negative impacts of tourism, such as increased pollution and direct pollution (e.g., direct discharge of sewage into the sea, destruction of the natural environment due to overcrowding of tourists, pollution from increased air and other traffic emissions). All this leads to the consideration that people who decide on the development of individual regions or countries make their decisions following the 2030 Agenda, preserve tourism businesses and services, and promote sustainable development. Tourism has become the largest service industry in the world. The number of tourists is constantly increasing, which also means that the impact and pressure on the environment are increasing. In response to mass tourism, new concepts and types of tourism have emerged, and several tourism strategies and policies have been developed that promote sustainable principles and allow for personalized tourism products and authentic destinations as added value.

It should be noted that economic performance is often mentioned in the literature as one of the important factors for sustainable behavior. In our opinion, this is becoming an increasingly important issue for the further development of tourism destinations. Therefore, it will be necessary to conduct thorough long-term research among stakeholders to 
explore the relationship between commercial success and ensuring and sustaining benefits for the local community.

Tourism is the industry that has been hit first and fastest by the coronavirus epidemic. The health crisis has resulted in global revenue from international tourism falling by about 63 per cent year-on-year in 2020, amounting to around US\$538 billion. In 2019, global inbound tourism revenue peaked at about US\$ 1.47 trillion [112]. Although a lightning recovery is expected, things will never be the same again. Therefore, it will be necessary to "reset" what has been achieved and develop new strategies that correspond to the new social manners.

For this reason, it is necessary to shed light on research questions related to the further development of sustainable tourism. Therefore, the central question is: what changes in the development of sustainable tourism are most likely to occur after the Corona crisis? The second question concerns whether a tourist destination has the knowledge to move from mass tourism to individual tourism, where the central theme of tourist services and products is focused on the integration of natural and cultural heritage to enable added value for the destination's rural ecosystem?

The first limitation of the study is the selection of WOS journals as the primary research source. However, this limitation can be overcome by including other documents such as books and conference papers and using the Scopus database as the primary source. The second limitation is that only English language papers were included, and the third is thematic. Finally, the fourth limitation arises from the use of ACA, which has advantages over manual data analysis, but this is a review study rather than primary research.

Author Contributions: The authors V.R., I.P. and M.M. contributed equally. All authors have read and agreed to the published version of the manuscript.

Funding: This research received no external funding

Informed Consent Statement: “Not applicable" for studies not involving humans.

Data Availability Statement: Not applicable.

Conflicts of Interest: The authors declare no conflict of interest

\section{References}

1. United Nations. Available online: Rio+20. Report on the UN Conference on Sustainable Development. http://www.uncsd2012.org/content/documents/814UNCSD\%20REPORT\%20final\% 20revs.pdf! (accessed on 21 September 2021).

2. Robertson V.J. Available online: UNESCO Statement for the World Summit on Ecotourism. http://www.unep.fr/shared/publications/cdrom/WEBx0139xPA/statmnts/pdfs/rouneef (accessed on 9 September 2021).

3. UNWTO - United Nations World Tourism Organisation. Available online: The Guidebook "Sustainable Tourism for Development", Brussels. http://icr.unwto.org/content/ guidebook-sustainable-tourism-development (accessed on 25 September 2021).

4. Nathaniel, S. P.; Adedoyin, F. F. Tourism development, natural resource abundance, and environmental sustainability: Another look at the ten most visited destinations. J. Pub. Aff. 2020, e2553. https://doi.org/10.1002/pa.2553

5. Casagrandi, R.; Rinaldi, S. A theoretical approach to tourism sustainability. Cons. Ecol. 2002, 6. 1, 13.

6. Lee, T. H.; Jan, F. H. (2018). Eco-tourism behavior of nature-based tourists: an integrative framework. J. Trav. Res. 2018, 57. 6, 792-810. https://doi.org/10.1177/0047287517717350

7. Wall, G. Is eco-tourism sustainable?. Env. Man. 1997, 21. 4, 483-491.

8. Line, N. D.; Hanks, L.; Miao, L. Image matters: Incentivising green tourism behavior. J. Trav. Res. 2018, 57. 3, $296-309$. https://doi.org/10.1177/00472875211011548

9. Burrai, E.; Buda, D. M.; Stanford, D. Rethinking the ideology of responsible tourism. J. Sust. Tour. 2019, 27. 7, 992-1007. https://doi.org/10.1080/09669582.2019.1578365

10. Asadi, S.; Pourhashemi, S. O.; Nilashi, M.; Abdullah, R.; Samad, S.; Yadegaridehkordi, E., ...; Razali, N. S. Investigating influence of green innovation on sustainability performance: A case on Malaysian hotel industry. J. Clean. Prod. 2020, $258,120860$. https://doi.org/10.1016/j.jclepro.2020.120860 
11. Cheng, M.; Edwards, D. A comparative automated content analysis approach on the review of the sharing economy discourse in tourism and hospitality. Curr. Iss. Tour. 2019, 22.1, 35-49.

12. Evangelista, P.; Santoro, L.; Thomas, A. A. Systematic literature review from 2000-2016. Sust. 2018 , 10 , 1627. https://doi.org/10.3390/su10051627

13. Blei, D. Probabilistic topic models. Commun. ACM 2012, 55, 77-84. https://doi.org/10.1145/2133806.2133826

14. Usai, A.; Pironti, M.; Mital, M.; Mejri, C.A. Knowledge discovery out of text data: A systematic review via text mining. J. Know. Man. 2018, 22, 1471-1488. https://doi.org/10.1108/JKM-11-2017-0517

15. Nunez-Mir, G.C.; Iannone, B.V., III; Pijanowski, B.C.; Kong, N.; Fei, S. Automated content analysis: Addressing the big literature challenge in ecology and evolution. Methods Ecol. Evol. 2016, 7, 1262-1272. https://doi.org/10.1111/2041-210X.12602

16. Leximancer. Leximancer User Guide. 2020. Available online: https://info.leximancer.com/ (accessed on 2 September 2021).

17. United Nations Sustainable Development Goals Knowledge Platform. Available online: https://sustainabledevelopment.un.org/outcomedocuments/agenda21 (accessed on 27 October 2021).

18. Maikhuri, R. K.; Rana, U.; Rao, K. S.; Nautiyal, S.; Saxena, K. G. Promoting eco-tourism in the buffer zone areas of Nanda Devi Biosphere Reserve: An option to resolve people-policy conflict. Int. J. Sust. Dev. E W. Ecol. 2020, 7. 4, $333-342$. https://doi.org/10.1080/13504500009470052

19. Yu, D. W.; Hendrickson, T.; Castillo, A. Eco-tourism and conservation in Amazonian Peru: short-term and long-term challenges. Env. Cons. 1997, 24. 2, 130-138. https://doi.org/10.1017/S0376892997000192

20. Walpole, M. J.; Goodwin, H. J. Local economic impacts of dragon tourism in Indonesia. Ann. Tour. Res. 2000, 27.3 , 559-576. https://doi.org/10.1016/S0160-7383(99)00088-2

21. Baker, J. E. Development of a model system for touristic hunting revenue collection and allocation. Tour. Man. 1997, 18. 5, 273286. https://doi.org/10.1016/S0261-5177(97)00016-2

22. Wearing, S.; Wearing, M. Decommodifying eco-tourism: Rethinking global-local interactions with host communities. Lo. et Soc./Soc. and Leis. 1999, 22. 1, 39-70. https://doi.org/10.1080/07053436.1999.10715575

23. Moscardo, G. Interpretation and sustainable tourism: Functions, examples and principles. J. Tour. Stud. 1998, 9. 1, 2.

24. Jurowski, C.; Olsen, M. D. Scanning the environment of tourism attractions: A content analysis approach. J. Trav. E Tour. Market. 1995, 4. 1, 71-96. https://doi.org/10.1300/J073v04n01_05

25. Simpson, F.; Roberts, L. Help or hindrance? Sustainable approaches to tourism consultancy in Central and Eastern Europe. J. Sust. Tour. 2000, 8. 6, 491-509. https://doi.org/10.1080/09669580008667382

26. Guthman, J. Representing crisis: The theory of Himalayan environmental degradation and the project of development in postRana Nepal. Dev. and Chan. 1997, 28.1, 45-69. https://doi.org/10.1111/1467-7660.00034

27. Collins, A. Tourism development and natural capital. Ann. Tour. Res. 1999, 26. 1, 98-109. https://doi.org/10.1016/S01607383(98)00059-0

28. Welford, R.; Ytterhus, B. Conditions for the transformation of eco-tourism into sustainable tourism. Eur. Environ. 1998, 8.6, 193201. https://doi.org/10.1002/(SICI)1099-0976(199811/12)8:6<193::AID-EET164>3.0.CO;2-4

29. Ross, S.; Wall, G. Eco-tourism: towards congruence between theory and practice. Tour. Man. 1999, $20.1,123-132$. https://doi.org/10.1016/S0261-5177(98)00098-3

30. Juda, L. Considerations in developing a functional approach to the governance of large marine ecosystems. Oc. Devel. E Int. Law 1999, 30.2, 89-125. https://doi.org/10.1080/009083299276203

31. Wescott, G. The development and initial implementation of Australia's 'integrated and comprehensive' Oceans Policy. Oc. E Coast. Man. 2000, 43, 10-11, 853-878. https://doi.org/10.1016/S0964-5691(00)00067-3

32. Clark, J. R. Coastal zone management for the new century. Oc. E Coast. Man. 1997, 37.2, 191-216. https://doi.org/10.1016/S09645691(97)00052-5

33. Kenchington, R.; Crawford, D. On the meaning of integration in coastal zone management. Oc. E Coast. Man. 1993, 21.1-3, 109127. https://doi.org/10.1016/0964-5691(93)90022-Q

34. Butler, R. W. Tourism, environment, and sustainable development. Environ. Cons. 1991, 18.3, 201-209. https://doi.org/10.1017/S0376892900022104

35. Sinclair, M. T. Tourism and economic development: A survey. The J. of Devel. Stud. 1998, 34.5, 1-51. https://doi.org/10.1080/00220389808422535

36. Hjalager, A. M. Consumerism and sustainable tourism. J. Trav. $\mathcal{E}$ Tour. Market. 2000, 8.3, 1-20. https://doi.org/10.1300/J073v08n03_01

37. Klenosky, D. B. (1998). Nature-based tourists' use of interpretive services: A means-end investigation. J. of Tour. Stud. 1998, 9.2, 26.

38. Von Frantzius, I. World Summit on Sustainable Development Johannesburg 2002: A critical analysis and assessment of the outcomes. Environ. Polit. 2004, 13. 2, 467-473. https://doi.org/10.1080/09644010410001689214

39. Castellani, V.; Sala, S. Sustainable performance index for tourism policy development. Tour. Man. 2010, 31.6, 871-880. https://doi.org/10.1016/j.tourman.2009.10.001

40. Framke, W. The destination as a concept: A discussion of the business-related perspective versus the socio-cultural approach in tourism theory. Scand. J. Hosp.Tour. 2002, 2.2, 92-108. https://doi.org/10.1080/15022250216287

41. De Carlo, M.; Dubini, P. Integrating heritage management and tourism at Italian cultural destinations. Int. J. Arts Man. $2010,12$. 2, 30-43.

42. Gössling, S. Sustainable tourism development in developing countries: Some aspects of energy use. J. Sust. Tour. 2000, 8.5, 410425. https://doi.org/10.1080/09669580008667376 
43. Cawley, M.; Gillmor, D. A. Integrated rural tourism: Concepts and Practice. Ann. Tour. Res. 2008, 35. 2, $316-337$.

44. Garrod, B.; Wornell, R.; Youell, R. Re-conceptualising rural resources as countryside capital: The case of rural tourism. J. Rur. Stud. 2006, 22.1, 117-128. https://doi.org/10.1016/j.jrurstud.2005.08.001

45. Vellecco, I.; Mancino, A. Sustainability and tourism development in three Italian destinations: stakeholders' opinions and behaviours. The Serv. Ind. J. 2010, 30.13, 2201-2223. https://doi.org/10.1080/02642060903287500

46. Scheyvens, R.; Momsen, J. H. Tourism and poverty reduction: Issues for small island states. Tour. Geog. 2008, 10.1, 22-41. https://doi.org/10.1080/14616680701825115

47. Uitto, J. I. International Cooperation for Sustainable Coastal and Marine Management in East Asia. Geog. Rev. Jap. 200376. $12,869-8$

48. White, A. T.; Courtney, C. A.; Salamanca, A. Experience with marine protected area planning and management in the Philippines. Coastal Management 2002, 30.1, 1-26. https://doi.org/10.1080/08920750252692599

49. Glavovic, B. C.; Boonzaier, S. Confronting coastal poverty: Building sustainable coastal livelihoods in South Africa. Oc. \& Coast. Man. 2007, 50. 1-2, 1-23. https://doi.org/10.1016/j.ocecoaman.2006.07.001

50. Nepal, S. K.; Chipeniuk, R. Mountain tourism: Toward a conceptual framework. Tour. Geog. 2005, 7.3, 313-333. https://doi.org/10.1016/j.ocecoaman.2006.07.001

51. Pereira, E.; Queiroz, C.; Pereira, H. M.; Vicente, L. Ecosystem services and human well-being: a participatory study in a mountain community in Portugal. Ecol. Soc. 2005, 10. 2, 14.

52. Bieger, T.; Wittmer, A. Air transport and tourism-Perspectives and challenges for destinations, airlines and governments. Journal of air transport management, 2006, 12.1, 40-46.

53. Khadaroo, J.; Seetanah, B. Transport infrastructure and tourism development. Ann. Tour. Res. 2007, 34.4, 1021-1032. https://doi.org/10.1016/j.annals.2007.05.010

54. Porter, D.; Craig, D. The third way and the third world: poverty reduction and social inclusion in the rise of 'inclusive'liberalism. Rev. Inter. Polit. Econ. 2004, 11.2, 387-423. https://doi.org/10.1080/09692290420001672881

55. Matarrita-Cascante, D. Beyond growth: Reaching tourism-led development. Ann. Tour. Res. 2010, 37.4, 1141-1163. https://doi.org/10.1016/j.annals.2010.05.004

56. Mbaiwa, J. E. The socio-cultural impacts of tourism development in the Okavango Delta, Botswana. J. Tour. Cult. Chan. 2005, 2.3, 163-185.

57. Padilla, M. B.; Guilamo-Ramos, V.; Bouris, A.; Reyes, A. M. HIV/AIDS and tourism in the Caribbean: an ecological systems perspective. Amer. J. Pub. Health 2010, 100.1, 70-77.

58. Cabezas, A. L. Economies of desire: Sex and tourism in Cuba and the Dominican Republic. Temple University Press: Philadelphia, 2009.

59. Juvan, E.; Dolnicar, S. The attitude-behaviour gap in sustainable tourism. Ann. Tour. Res. 2014, 48, 76-95. https://doi.org/10.1016/j.annals.2014.05.012

60. Carlisle, S.; Kunc, M.; Jones, E.; Tiffin, S. Supporting innovation for tourism development through multi-stakeholder approaches: Experiences from Africa. Tour. Man. 2013, 35, 59-69. https://doi.org/10.1016/j.tourman.2012.05.010ž

61. Minciu, R.; Pădurean, M.; Popescu, D.; Hornoiu, R. Demand for Vacations/Travel in Protected Areas-Dimension of Tourists' Ecological Behavior. Amfit. Econ. J. 2012, 14.31, 99-113.

62. Ramos, A. M.; Prideaux, B. Indigenous ecotourism in the Mayan rainforest of Palenque: empowerment issues in sustainable development. J. Sust. Tour., 2014, 22.3, 461-479. https://doi.org/10.1080/09669582.2013.828730

63. Romão, J.; Neuts, B.; Nijkamp, P.; Shikida, A. Determinants of trip choice, satisfaction and loyalty in an eco-tourism destination: A modelling study on the Shiretoko Peninsula, Japan. Ecol. Econ. 2014, 107, 195-205. https://doi.org/10.1016/j.ecolecon.2014.07.019

64. Gössling, S.; Scott, D.; Hall, C. M.; Ceron, J. P.; Dubois, G. Consumer behaviour and demand response of tourists to climate change. Ann. Tour. Res. 2012, 39.1, 36-58. https://doi.org/10.1016/j.annals.2011.11.002

65. Chen, W.-J.; Liaw, S.-C. What is the value of eco-tourism? An evaluation of forested trails for community residents and visitors. Tour. Econ. 2012, 18.4: 871-885.https://doi.org/10.5367/te.2012.0146

66. Khakzad, S.; Pieters, M.; Van Balen, K. Coastal cultural heritage: A resource to be included in integrated coastal zone management. Oc. E Coast. Man. 2015, 118, 110-128. https://doi.org/10.1016/j.ocecoaman.2015.07.032

67. Carneiro, M. J.; Lima, J.; Silva Lavrador A. Landscape and the rural tourism experience: identifying key elements, addressing potential, and implications for the future. J. Sust. Tour., 2015, 23.8-9, 1217-1235. https://doi.org/10.1080/09669582.2015.1037840

68. Bohnet, I. C.; Konold, W. New approaches to support implementation of nature conservation, landscape management and cultural landscape development: experiences from Germany's southwest. Sust. Sci., 2015, 10.2: $245-255$. https://doi.org/10.1007/s11625-015-0290-z

69. McAreavey, R.; McDonagh, J. Sustainable rural tourism: Lessons for rural development. Soc. Rur., 2011, 51.2, 175-194. https://doi.org/10.1111/j.1467-9523.2010.00529.x

70. McGehee, N. G.; Knollenberg, W.; Komorowski, A. The central role of leadership in rural tourism development: A theoretical framework and case studies. J. Sust. Tour. 2015, 23.8-9, 1277-1297. https://doi.org/10.1080/09669582.2015.1019514

71. Komppula, R. The role of individual entrepreneurs in the development of competitiveness for a rural tourism destination-A case study. Tour. Man. 2014, 40, 361-371. https://doi.org/10.1016/j.tourman.2013.07.007

72. Cazcarro, I.; Hoekstra, A. Y.; Chóliz, J. S. The water footprint of tourism in Spain. Tour. Man. 2014, 40, 90-101. https://doi.org/10.1016/j.tourman.2013.05.010 
73. Schmidt, L., Gomes, C., Guerreiro, S., \& O’Riordan, T. (2014). Are we all on the same boat? The challenge of adaptation facing Portuguese coastal communities: Risk perception, trust-building and genuine participation. Land Use Policy, 38, 355-365.

74. Semeoshenkova, V.; Newton, A. Overview of erosion and beach quality issues in three Southern European countries: Portugal, Spain and Italy. Oc. E Coast. Man. 2015, 118, 12-21. https://doi.org/10.1016/j.ocecoaman.2015.08.013

75. Lucrezi, S.; Saayman, M.; Van der Merwe, P. Managing beaches and beachgoers: Lessons from and for the Blue Flag award. Tour. Man. 2015, 48, 211-230. https://doi.org/10.1016/j.tourman.2014.11.010

76. Coles, T.; Fenclova, E.; Dinan, C. Tourism and corporate social responsibility: A critical review and research agenda. Tour. Man. Persp. 2013, 6, 122-141. https://doi.org/10.1016/j.tmp.2013.02.001

77. McCombes, L.; Vanclay, F.; Evers, Y. Putting social impact assessment to the test as a method for implementing responsible tourism practice. Env. Imp. Assess. Rev. 2015, 55, 156-168. https://doi.org/10.1016/j.eiar.2015.07.002

78. Razumova, M.; Ibáñez, J. L.; Palmer, J. R. M. Drivers of environmental innovation in Majorcan hotels. Journal of Sustainable Tourism 2015, 23(10), 1529-1549. https://doi.org/10.1080/09669582.2015.1062016

79. Tugores, M.; García, D. The impact of innovation on firms' performance: an analysis of the hotel sector in Majorca. Tour. Econ., 2015, 21.1: 121-140. https://doi.org/10.5367/te.2014.0440

80. Timms, B. F.; Conway, D. Slow tourism at the Caribbean's geographical margins. Tour. Geog. 2012, 14.3, 396-418. https://doi.org/10.1080/14616688.2011.610112

81. Özdemir, G.; Yilmaz, M.; Yalçin, M.; Alvarez, M. D. Stakeholders' perception of Istanbul's historical peninsula as a sustainable destination. Tour. Plan. Develop. 2015, 12.1, 87-98. https://doi.org/10.1080/21568316.2014.960596

82. United Nations. Transforming Our World. The 2030 Agenda for Sustainable Development. Available online: https://sustainabledevelopment.un.org/post2015/transformingourworld (accessed on 21 August 2021).

83. Bali Swain, R.; Yang-Wallentin, F. Achieving sustainable development goals: predicaments and strategies. Int. J. Sust. Dev. W. Ecol. 2020, 27.2., 96-106. https://doi.org/10.1080/13504509.2019.1692316

84. Galli, A.; Đurović, G.; Hanscom, L.; Knežević, J. Think globally, act locally: Implementing the sustainable development goals in Montenegro. Env. Sc. Pol. 2018, 84, 159-169. https://doi.org/10.1016/j.envsci.2018.03.012

85. Caust, J.; Vecco, M. Is UNESCO World Heritage recognition a blessing or burden? Evidence from developing Asian countries. J. Cult. Her. 2017, 27, 1-9. https://doi.org/10.1016/j.culher.2017.02.004

86. Lak, A.; Gheitasi, M.; Timothy, D. J. Urban regeneration through heritage tourism: cultural policies and strategic management. J. Tour. Cult. Ch. 2020, 18.4, 386-403. https://doi.org/10.1080/14766825.2019.1668002

87. Seyfi, S.; Hall, M.C.; Fagnoni, E. Managing world heritage site stakeholders: A grounded theory paradigm model approach. J. Herit. Tour. 2019, 14.4, 308-324. https://doi.org/10.1080/1743873X.2018.1527340

88. Duarte Alonso, A.; Sakellarios, N.; Pritchard, M. The theory of planned behaviour in the context of cultural heritage tourism. J. Herit. Tour. 2015, 10.4, 399-416.

89. Tuomi, A.; Tussyadiah, I.; Ling, E. C.; Miller, G.; Lee, G. $\mathrm{x}=($ tourism_work) $\mathrm{y}=(\mathrm{sdg} 8)$ while $\mathrm{y}=$ true: automate (x). Ann. Tour. Res. 2020, 84, 102978. https://doi.org/10.1016/j.annals.2020.102978

90. Movono, A.; Hughes, E. (2020). Tourism partnerships: Localising the SDG agenda in Fiji. J. Sust. Tour. https://doi.org/10.1080/09669582.2020.1811291

91. Xiao, W.; Mills, J.; Guidi, G.; Rodríguez-Gonzálvez, P.; Barsanti, S. G.; González-Aguilera, D. Geoinformatics for the conservation and promotion of cultural heritage in support of the UN Sustainable Development Goals. ISPRS J. Phot. Rem. Sens. 2018, 142, 389-406. https://doi.org/10.1016/j.isprsjprs.2018.01.001

92. Aquino, R. S.; Lück, M.; Schänzel, H. A. A conceptual framework of tourism social entrepreneurship for sustainable community development. J. Hosp. Tour. Man. 2018, 37, 23-32. https://doi.org/10.1016/j.jhtm.2018.09.001

93. Petrović, N.; Roblek, V.; Papachashvili, N. Decision support based on data mining for post COVID-19 tourism industry. In Proceedings of the XV International SAUM Conference, Niš, Serbia, $9^{\text {th }}-10^{\text {th }}$ September 2021.

94. Peterlin, J.; Meško, M.; Dimovski, V.; Roblek, V. Automated content analysis: The review of the big data systemic discourse in tourism and hospitality. Syst. Res. Beh. Sc. 2021, 38.3, 377-385. https://doi.org/10.1002/sres.2790

95. Beck, J.; Rainoldi, M.; Egger, R. Virtual reality in tourism: A state-of-the-art review. Tour. Rev. 2019, 74.3, 586-612. https://doi.org/10.1108/TR-03-2017-0049

96. Cranmer, E. E.; tom Dieck, M. C.; Fountoulaki, P. Exploring the value of augmented reality for tourism. Tour. Man. Pers. 2020, 35, 100672. https://doi.org/10.1016/j.tmp.2020.100672

97. Wang, W.; Kumar, N.; Chen, J.; Gong, Z.; Kong, X.; Wei, W.; Gao, H. Realizing the Potential of Internet of Things for Smart Tourism with 5G and AI. IEEE Net. 2020, 34.6, 295-301.

98. Gupta, S.; Kumar, V.; Karam, E. New-age technologies-driven social innovation: What, how, where, and why?. Ind. Mark. Man. 2020, 89, 499-516. https://doi.org/10.1016/j.indmarman.2019.09.009

99. Carvajal, D. A. L.; Morita, M. M.; Bilmes, G. M. Virtual museums. Captured reality and 3D modeling. J. Cult. Herit. 2020, 45, 234-239.

100. Petrović N.; Roblek, V.; Khokhobaia, M.; Gagnidze, I. AR-enabled mobile apps to support post COVID-19 tourism. In Proceeding of the $15^{\text {th }}$ International Conference on Advanced Technologies, Systems and Services in Telecommunications (TELSIKS), Niš, Serbia, 20-22 October 2021.

101. Mohanty, P.; Hassan, A.; Ekis, E. Augmented reality for relaunching tourism post-COVID-19: socially distant, virtually connected. World. Hosp. Tour. Th. 2020, 12.6, 753-760. https://doi.org/10.1108/WHATT-07-2020-0073

102. Petrović, N.; Tošić, M.; Nejković, V. AR-enabled mobile apps for robot coordination. Proceedings of the 7th Conference with International Participation Knowledge Management and Informatics, Kopaonik, Serbia, 11-13 January 2021. 
103. Roblek, V.; Petrović, N.; Gangidnze, I.; Khokhobaia, M. Role of a digital transformation in development of a rural tourism destinations. In Proceedings of the VI. International Scientific Conference, Tbilisi State University, Tbilisi, 5 November 2021.

104. Ivanova, M.; Ivanov, S. Tourism information technology. J. Tour. Fut. 2020, 6.2, 201-202. https://doi.org/10.1108/JTF-06-2020-153

105. Nunes, S.; Cooke, P. New global tourism innovation in a post-coronavirus era. Eur. Plan. Stud. 2021, 29.1, 1-19. https://doi.org/10.1080/09654313.2020.1852534

106. Higgins-Desbiolles, F. The "war over-tourism": challenges to sustainable tourism in the tourism academy after COVID-19. J. Sust. Tour. 2020, 29.4, 551-569. https://doi.org/10.1080/09669582.2020.1803334

107. Romagosa, F. The COVID-19 crisis: Opportunities for sustainable and proximity tourism. Tour. Geog. 2020, 22.3, 690-694. https://doi.org/10.1080/14616688.2020.1763447

108. Cunha, C.; Kastenholz, E.; Carneiro, M. J. Entrepreneurs in rural tourism: Do lifestyle motivations contribute to management practices that enhance sustainable entrepreneurial ecosystems?. J. Hosp. Tour. Man. 2020, 44, $215-226$. https://doi.org/10.1016/j.jhtm.2020.06.007

109. Richards, G. Designing creative places: The role of creative tourism. Ann. Tour. Res. 2020, 85, 102922. https://doi.org/10.1016/j.annals.2020.102922

110. Roxas, F. M. Y.; Rivera, J. P. R.; Gutierrez, E. L. M. Mapping stakeholders' roles in governing sustainable tourism destinations. J. Hosp. Tour. Man. 2020, 45, 387-398. https://doi.org/10.1016/j.jhtm.2020.09.005

111. Von Wirth, T.; Fuenfschilling, L.; Frantzeskaki, N.; Coenen, L. Impacts of urban living labs on sustainability transitions: Mechanisms and strategies for systemic change through experimentation. Europe. Plan. Stud. 2019, 27.2, $229-257$. https://doi.org/10.1080/09654313.2018.1504895

112. Statista. International tourism receipts worldwide from 2006 to 2020. Available online: https://www.statista.com/statistics/273123/total-international-tourism-receipts/ (accessed on 19 September 2021). 